Agro-Science Journal of Tropical Agriculture, Food, Environment and Extension Volume 20 Number 3 (July 2021) pp. $37-48$

ISSN 1119-7455

\title{
INFLUENCE OF SLOPE ASPECT AND POSITION ON SOIL PHYSICAL QUALITY AND MANAGEMENT IMPLICATIONS AT UNIVERSITY OF UYO TEACHING AND RESEARCH FARM, AKWA IBOM STATE, NIGERIA
}

\author{
Ogban P.I. \\ Department of Soil Science, Faculty of Agriculture, Forestry \& Wildlife Resources Management, \\ University of Calabar, Calabar, Cross River State, Nigeria
}

Corresponding author's email: peterogban@gmail.com; peterogban@unical.edu.ng

\begin{abstract}
The effect of north and south aspects (NA and SA) and positions viz upper (US), middle (MS) and lower (LS) on soil physical quality from 2000 to 2020 was evaluated at the University of Uyo Teaching \& Research Farm, to identify management factors at the Farm. Results showed that coarse sand increased while clay content decreased significantly $(p<0.05)$ and soil textural class was loamy sand on slope aspects and positions. Soil bulk density and total porosity were similar on the slope aspects and positions. Saturated hydraulic conductivity was significantly $(p<0.05)$ higher on $S A\left(10.6 \mathrm{~cm} \mathrm{~h}^{-1}\right)$ than $\mathrm{NA}\left(3.1 \mathrm{~cm} \mathrm{~h}^{-1}\right)$ but declined by 93.03\% and 52.47\%, respectively in 20 years. Soil organic carbon, water-stable aggregates, mean-weight diameter of soil aggregates and structural index decreased by $14.81 \%$ and $38.33 \%, 60.53 \%$ and $55.53 \%$, $31.26 \%$ and $21.71 \%$, and $48.60 \%$ and $69.0 \%$, respectively in $N A$ and $S A$ within the 20-year period. One minute infiltration rate was similar on $N A$ and $S A$, while final infiltration rate, cumulative infiltration, sorptivity and transmissivity were significantly $(p<0.05)$ different; these soil hydraulic properties decreased in $\mathrm{NA}$ and $\mathrm{SA}$ by $83.0 \%$ and $86.43 \%, 52.63 \%$ and $14.29 \%, 81.53 \%$ and $63.9 \%, 95.0 \%$ and $85.63 \%$ and $90.42 \%$ and $96.11 \%$, respectively on the aspects after the 20 years. Slope aspects and positions were generally similar in their effects on soil physical quality attributes, most of which were degraded after the 20 years. Principal component analysis (PCA) identified seven soil quality management factors namely (1) water intake, (2) soil texture, (3) soil pore space, (4) and (6) Fe and Al oxide, and (5) and (7) soil structural stability factors that could be used to improve and conserve the soil and water for increases in crop production on the farm.
\end{abstract}

Key words: crop residues, infiltration characteristics, soil functions, soil structural stability, soil quality

\section{INTRODUCTION}

Knowledge of soil physical quality (SPQ) attributes is important in developing stable and viable soil management practices that will conserve the soil resource base and its properties and processes and functions. Soil quality generally can be defined as the degree of fitness of a soil for a specific use (Carter et al., 1997). Soil quality also implies other concepts such as the sustained capability of a soil to accept, store, and recycle water, nutrients and energy. It is a unique balance and interaction of its physical, chemical and biological components (Karlin et al., 1997; Herrick et al., 2002; Aparicio and Costa, 2007). Soil quality is dynamic and often assessed based on soil function (Doran and Parkin, 1996), to ascertain whether it is improving, stable or declining with soil use. This is because it is deemed important for the assessment of the extent of land degradation or amelioration, and for identifying management practices for sustainable land use. Consequently, good SPQ occurs when soils exhibit the absence of degradative symptoms such as poor water infiltration, which reflect poor soil structure.
Soil physical properties profoundly influence how soils function in an ecosystem and how they can best be managed (Weil and Brady, 2017). Soil physical quality, also termed soil physical fertility, is the component contribution of the soil physical properties and processes to the ability of the soil to perform its functions and support ecosystem services (Scott, 2000; Yaalon and Arnold, 2000). Shukla (2014) stated that the quality of land is dependent on its physical properties. Lal (1999) and Lal and Shukla (2005) reported that high SPQ plays an important role in enhancing soil chemical and biological qualities and hence in defining the overall productivity of the soil, as well as in sustainable management of natural resources.

The soil physical properties that profoundly influence soil's static and transmission properties are soil texture and the more dynamic soil structure (Pierce et al., 1983; Rawls et al., 1998; Zimmermann et al., 2013) and can be used as indicators of soil quality (Arshad et al., 1996), and to determine the ability of the soil to function. Larson and Pierce (1991) suggested three principal

Please cite as: Ogban P.I. (2021). Influence of slope aspect and position on soil physical quality and management implications at University of Uyo Teaching and Research Farm, Akwa Ibom State, Nigeria. Agro-Science, 20 (3), $37-48$. DOI: https://dx.doi.org/10.4314/as.v20i3.6 
functions that a soil must perform; (1) provide a medium for plant growth, (2) regulate and partition water flow in the environment, and (3) serve as an environmental filter. To perform these functions, however, a soil must resist erosion and runoff, and accept and transmit water. Soil quality assessment is thus purpose- and site-specific, and is a tool focused on dynamic soil properties and processes, while not ignoring the inherent soil properties (Karlen et al., 2003), that are useful for assessing the ability of a soil to sustain crop production and the sustainability of soil management practices.

Soil quality cannot be measured directly but inferred by measuring soil attributes or properties that are sensitive to changes in soil functions (Doran and Jones, 1996; Aparicio and Costa, 2007; Dexter and Czyz, 2007). It is thus important to build a simple, sensitive, and workable indicator method for soil quality evaluation (Dumanski and Pieri, 2000). For this reason, soil quality is evaluated by use of a minimum data set (MDS) of indicators (Karlen and Stott, 1994; Doran and Parkin, 1996; Karlen et al., 1997), measurable against some definable standards and sensitive to soil management (Doran and Parkin, 1996; Larson and Pierce, 1994; Karlen et al., 1997, 1998; Andrews et al., 2002). For instance, Tisdall and Oades (1982), Churchman and Tate (1987) and Pajasok and Kay (1990) suggested soil organic carbon (SOC) content as a soil quality indicator because decreases in this parameter can be related to decreased water stability of macroaggregates and microaggregates and soil's resistance to erosion and runoff, as well as water infiltration, storage and transmission (Miller and Baharuddin, 1986; Stern et al., 1991).

Notably, soil quality can be evaluated at several different scales (Karlen et al., 1997). For instance, Karlen et al. (1999), Liebig and Doran (1999), and Brejda et al. (2000) evaluated soil quality indicators from point to regional scales. Cambardella et al. (2004) assessed soil quality on a watershed scale by sampling along transects along topographic gradients, and then used terrain analysis to group the data into landform classes. This allowed them to evaluate the effect of topographic position on soil quality. They documented soil quality differences by (i) quantifying soil indicator variables, (ii) calculating soil quality indices, and (iii) comparing indicator variable and index results with independent assessment of soil function endpoints such as sediment loss, water partitioning at the soil surface, and crop yield. Some have suggested indicators that reflect changes over various spatial and temporal scales (Arshad and Coen, 1992), including longterm field studies (Karlen et al., 1994). Karlen et al. (1994) developed a soil quality index based on four soil functions: (i) infiltration; (ii) water holding capacity and transmission; (i) degradation resistance; and (iv) supporting plant growth.
Dexter (2004), based on the observations of Dexter and Czyz (2000), proposed a SPQ index, $S$, that enables different soils and the effects of different management treatments and conditions to be compared directly. Pulido Moncada et al. (2015) reported that the use of $S$ as an indicator to be considered as part of a MDS of indicators of SPQ assessment is less viable when other indicators such as bulk density, porosity, and visual examination are much more easily determined and more consistent than $S$. They concluded therefore, that it is too ambitious to consider that a unique indicator such as the $S$ index could be used to evaluate SPQ as such. Although much has been achieved in the evaluation of soil quality, there is yet no universally agree on its evaluation; therefore, a wide variety of methods using vastly different indicators and indexes are used to evaluate soil quality (Qi et al., 2009; Mukherjee and Lal, 2014).

Many of the soil attributes that contribute to soil quality are highly correlated; functioning in concert with other soil attributes (Larson and Pierce, 1991; Seybold et al., 1997). Consequently, soil quality or SPQ may be assessed by evaluating several soil attributes simultaneously using statistical procedures that account for correlations among soil attributes (Brejda et al., 2000). Multivariate statistical analyses provide techniques for simultaneously analyzing correlated variables. Factor analysis is a multivariate procedure used to describe the interrelationships among many correlated variables in terms of a few underlying factors (Johnson and Wichern, 1992). With factor analysis, a large number $(p)$ of correlated variables are reduced to $m<p$ uncorrelated factors that are linear functions of the original variables. Each factor is responsible for the correlation among the group of correlated attributes that comprise it (Johnson and Wichern, 1992). If these factors can be related to soil functions, they could represent soil quality factors. Changes in the soil attributes that comprise each soil quality factor could be used to assess soil stability to use and management.

Land use and soil management primarily affect the dynamic properties of soil by changing soil structure and affecting SPQ (Lal and Shukla, 2005). On the other hand, Jenny (1941) had observed that soils and soil properties are known to be configurations of environmental or state factors at a given location. It is common knowledge that topography significantly affects soil characteristics (Ollinger et al., 2002; Yimer et al., 2006) because its slope element drives geomorphic processes (Evans, 1972), retard or accelerate (Weil and Brady, 2017) and cause the convergence or divergence of fluxes of materials on the landscape. Therefore, soils differ in their characteristics primarily because of topography (Aduloju and Tetengi, 2011), and because topography modifies the climate elements (Weil and Brady, 2017). 
One reason for variation in soil properties with topographic settings is the orientation of the slopes on which soils develop, and the micro-climate (Iqbal et al., 2004). Geroy et al. (2011) observed that soil water retention properties are primarily controlled by soil texture, which in turn varies spatially in response to microclimate-induced differences in isolation, wetness and temperature, all of which can be strongly differentiated by slope aspect. Geroy et al. (2011) also reported that soil porosity, soil organic matter and silt content were greater and more water stored on the north aspect than south aspect. Weil and Brady (2017) observed that south-facing slopes are more perpendicular to the sun's rays and are generally warmer and thereby commonly lower in moisture than their north-facing counterparts. Consequently, soils on the south slopes tend to be lower in organic matter and are not so deeply weathered. Ogban and Okon (2020) reported that infiltration characteristics were generally higher on north than south aspects.

Soil quality is a subject that is receiving increasing attention (e.g., Wilson and MaliszewskaKordybach, 2000). However, research in soil quality is scarce in southern Nigeria. And, although much data on inherent soil properties have been generated over the years, no attempt has been made to integrate them into management categories based on their correlation structures on the Farm of the University of Uyo. The objectives of this study were to (i) evaluate the effects of slope aspect and position on SPQ attributes after 20 years of cultivation and (ii) identify quality soil management attribute-factors that could be used to enhance perceived soil functions for sustainable increases in crop production on this University Farm, relying on Enwezor et al. (1990), Ogban et al. (2000), Mukherjee and Lal (2014) and Pulido Moncada et al. (2015), adopting the broad categories of 'more is better,' 'less is better,' or 'optimum range' approach (Sojka and Upchurch, 1999).

\section{MATERIALS AND METHODS}

\section{Study Area}

The study which evaluated the status of SPQ between the years 2000 (Ogban et al., 2000) and 2020, was conducted in the University of Uyo Teaching \& Research Farm at Use Offot, in Akwa Ibom State. The Farm is 136-ha and has been cultivated for over 30 years. The Farm is located between latitudes $5^{\circ} 00^{\prime}$ and $5^{\circ} 10^{\prime}$ and longitudes $7^{\circ} 50^{\prime}$ and $8^{\circ} 00^{\prime}$. It is bisected by a dry valley with two opposing moderate slopes averaging $12 \%$ and $10 \%$ on the north aspect (NA) and the south aspect (SA), respectively.

The climate of the area is generally hot humid tropical characterized by distinct wet and dry seasons (Inyang, 1975). On the average, the wet or rainy season lasts from April to October and the dry season lasts from November to March, with variations in some years, and recently due to climate change. Generally, the rainfall regime is characterized by heavy storms of high erosion potential and the annual average rainfall may be over $2,500 \mathrm{~mm}$. The average annual temperature is about $26^{\circ} \mathrm{C}$ and the relative humidity is about $70 \%$ (Petters et al., 1989; Udosen, 2017).

The study area is mostly flat-lying to gently undulating relief. However, slopes ranging from $5 \%$ to $>20 \%$ occur in some places. It is underlain by the Coastal Plain Sands consisting of tertiary unconsolidated sands deposits known as the Benin formation (Ojanuga et al., 1981). The soils are classified as Ultisols (Keys to Soil Taxonomy, 2020) or Acrisol (FAO, 2014), and are characterized by sandy texture and low fertility due to dominance of kaolinitic, low-activity clays and low contents of organic matter (Ofomata, 1981; Ojanuga et al., 1981; Enwezor et al., 1990; Ogban and Ekerette, 2001; Chikezie et al., 2010; Akamigbo and Nnaji, 2011). The soils are deeply weathered and poorly structured; hence they are permeable and droughty. A variety of bad soil-use practices, including bare cultivation, are common in the area. Also, rapid loss of surface coverage and over dependence on low-input farming are among the drivers of land degradation here. The poor soil conditions coupled with rainstorms and degradative soil-use practices often reduce the soils' capacity to function optimally (Petters et al., 1989; Ogban and Ekerette, 2001; Udosen, 2017).

\section{Field Study}

The study was conducted on $12 \%$ NA and $10 \%$ SA. At the time of the study, the middle slope of NA and crest of SA were under cassava/ pumpkin intercrop and garden egg, respectively. Other slope positions on NA and SA were under a two-year natural fallow. A transect was taken from the crest to the valley bottom of each slope aspect. Each of the two slope aspects was then categorized into three slope positions namely upper (US), middle (MS) and lower (LS) slope positions. At each position, two sampling points $5 \mathrm{~m}$ apart were taken on either side of the transect. At each point, three random samples were collected from the top- $(30 \mathrm{~cm})$ soil layer using a spade and bulked to give a total of 24 $(4 \times 3 \times 2)$ samples for the determination of particle-size fractions, aggregate-size distribution, and contents of SOC and amorphous and crystalline oxides iron and aluminum. A set of two undisturbed core samples was also collected with metal cylinders of $7.20 \mathrm{~cm}$ height and $6.80 \mathrm{~cm}$ internal diameter at each slope position and on either side of the transect, giving $12(2 \times 3 \times 2)$ for the determination of soil bulk density and saturated hydraulic conductivity, $K_{s}$. Four infiltration runs were carried out with the double ring infiltrometer (Reynolds et al., 2002) for a duration of $3 \mathrm{~h}$ at each slope position, and at $5 \mathrm{~m}$ intervals on either side of the transect. Measured cumulative infiltration was used to compute the infiltration rate $\left(i_{o}\right)$, steady-state infiltration $\left(i_{c}\right)$, and the curve-fitting procedure was used to obtain the soil sorptivity $(S)$, and soil transmissivity $(A)$. 


\section{Soil Physical Quality (SPQ) Assessment}

The bulk soil samples were analyzed for some SPQ properties. Particle-size was analysis was done as described in Gee and Or (2002). Structural stability of the soil was inferred by water-stable aggregates (WSA) $\geq 0.25 \mathrm{~mm}$, and by mean-weight diameter (MWD) of WSA $\leq 4.75 \mathrm{~mm}$ (Nimmo and Perkins, 2002). To compute these indices, the aggregates were first physically separated in five size fractions; $>2000,1000-2000,250-1000$, and 50-250 $\mu \mathrm{m}$, including the mineral fraction (silt + clay) $<50 \mu \mathrm{m}$ in diameter. The $\% \mathrm{WSA}>0.25 \mathrm{~mm}$ for the $i$ th fraction was computed according to Hillel (1980) thus:

$$
W S A_{i}=\left[\frac{M_{\text {soil. } i}-M_{\text {sand. } i}}{M_{\text {soil. }}-M_{\text {sand.t }}}\right]
$$

where Msoil, $i$ is the mass of oven-dry soil sample after wet-sieving for the $i$ th fraction, Msand, $i$ is the oven-dry mass of sand for the $i$ th fraction, Msoil, $t$ is the mass of the whole sample, and Msand, $t$ is the mass of sand in the whole sample. Correction for sand was done to take care of differences in contents of total sand. The MWD was calculated as follows:

$$
M W D(m m)=\sum_{i=1}^{n} w_{i} m_{i}
$$

where $w_{i}$ is the mean diameter of a given size class $(\mathrm{mm}), m_{i}$ is the fractional mass of a given size class $\left(\mathrm{g} \mathrm{g}^{-1}\right)$, and $n$ is the number of sieves used. The soil structural stability index, which expressed the risk of soil structural degradation associated with SOC depletion (Pieri, 1992), was calculated thus:

$$
S I=\left[\frac{1.72 x S O C}{S i+C l}\right] 100
$$

where $S I$ is structural stability index of the soils $(\%), S i$ is total silt (\%), and $\mathrm{Cl}$ is total clay (\%) in the soils. As did Obalum et al. $(2011,2013)$ and Obalum and Obi $(2013,2014)$, the index was used to group the soils according to their stability.

The higher the value of the above indices, the more stable the soil is. The $K_{s}$ was determined as described by Reynolds and Elrick (2002). Thereafter, soil bulk density determined by the procedure of Grossman and Reinsch (2002) and total pore space computed (Flint and Flint, 2002). Soil water sorptivity and transmissivity were estimated from the Philip's (1957) two-term algebraic equation:

$$
I=S \sqrt{ } t+A t
$$

where $I$ is cumulative infiltration $(\mathrm{cm}), t$ is elapsed time (h), $S$ is the soil water sorptivity $\left(\mathrm{cm} \mathrm{t}^{-1 / 2}\right)$, and $A$ is the soil water transmissivity $\left(\mathrm{cm} \mathrm{h}^{-1}\right)$. The SOC was determined by the modified WalkleyBlack method of Nelson and Sommers (1996). Crystalline and non-crystalline (amorphous) oxides of $\mathrm{Fe}$ and $\mathrm{Al}$ were extracted by the dithionitecitrate-bicarbonate $\left(\mathrm{Fe}_{\mathrm{di}}\right.$ and $\left.\mathrm{Al}_{\mathrm{di}}\right)$ solution $(\mathrm{DCB})$ and $0.2 M$ ammonium oxalate $\left(\mathrm{Fe}_{\mathrm{ox}}\right.$ and $\left.\mathrm{Al}_{\mathrm{ox}}\right)$ solution $(\mathrm{Ox})$ at $\mathrm{pH}$ 3.0. Dissolved Fe and $\mathrm{Al}$ were measured using Atomic Absorption Spectrophotometer (McKeague and Day, 1966).

\section{Statistical Analysis}

Data were subjected to two-way analysis of variance (ANOVA) at the 5\% probability level for differences in SPQ among the slope aspects and positions. The data were also subjected to Pearson's correlations and standardized principal component analysis (PCA) to identify best management practices for the sustainable uses of soil of the Farm. The PCA was performed on all untransformed data that showed significant differences between the slope aspects and positions based on the ANOVA to select a minimum dataset (MDS) of best indicators of soil functions at the Farm. Principal components (PCs) for a dataset are defined as linear combinations of the variables such that the strategy described here is similar to that described by Dunteman (1989). We assume that PCs with high values best represent system attributes. Therefore, we examined only the PCs with eigen values $\geq 1$ (Brejda et al., 2000).

\section{RESULTS AND DISCUSSION Effects of Slope Aspect on Soil Properties Particle-size distribution}

The results show that particle-size fractions were similar on NA and SA but dominated by total sand $>85 \%$ and $>75 \%$, respectively in the year 2020 (Table 1). Also, total sand was about $13 \%$ (NA) and $8 \%$ (SA) higher in Table 1 than in the year 2000 (Table 2). Similarly, coarse sand was about $70 \%$ and $11 \%$ higher than fine sand in 2020 than 2000 , respectively, implying that over a 20 -year period, about $59 \%$ of fine sand was lost on both aspects. Also, both aspects lost respectively $45 \%$ and $29 \%$ fine sand over the period. During the period too, NA and SA lost, respectively, $49 \%$ and $45 \%$ of their clay content. Thus, the increased content of total sand and/or coarse sand and decreased contents of fine sand and clay in the surface $(30 \mathrm{~cm})$ layer either by infiltrating water and/or surface wash, indicated severe erosion in this layer; the losses, though similar, appeared to be higher on NA than SA. The loss of colloidal materials in a soil negates aggregation because it disrupts the electrostatic bonding of the primary particles in the early stages of formation and stabilization of microstructure. Consequently, bare cultivation encouraged soil erosion, requiring the adoption of appropriate soil management practices in the study area.

Soil texture on both aspects was generally loamy sand ( $\geq 85 \%$ ) (Babalola and Obi, 1981). The similarity in texture is ascribed to the parent material and soil erosion processes on the Farm over the years. The sandy texture of the soils on both slopes implies that textural pores may have been skewed toward macropores that facilitate the entry of water and high internal drainage, negating its ability to hold and supply water for crop production. This is so because soil texture affects soil pore geometry, pore-size distribution and the absorptive and capillary potentials (Warrick and Nielsen, 1980), and thus water economy of crop rooting zone. 


\section{Soil bulk density and total porosity}

Soil bulk density showed marginal changes, being $3.85 \%$ higher in NA and $4.97 \%$ lower in SA during the 20-year period (Tables 1 and 2). Similarly, soil total porosity increased by $1.18 \%$ in NA and $7.93 \%$ in SA. These marginal changes imply that the loss of fine sand and clay and the abundance of coarse sand did not influence the preponderance of pores in the soils. However, compared with $1.33 \mathrm{Mg} \mathrm{m}^{-3}$ lower and $1.48 \mathrm{Mg} \mathrm{m}^{-3}$ upper critical limits for mediumtextured soils (Mukherjee and Lal, 2014; Pulido Moncada et al., 2015), the values in Tables 1 and 2 were fairly high and the soil on both aspects deemed compacted and hence degraded in the $30 \mathrm{~cm}$ depth, despite the continual tillage operation. The observed soil density values are attributed to the dominance of quartz in the soils. Bulk density and porosity are indexes of soil texture and structure, or the geometric arrangements of the particles and their dynamics (Lal and van Doren, 1990; Franzluebbers, 2002). They are an indicator of soil quality (Lal et al., 1998), influencing soil hydraulic and water transmission properties (Rawls et al., 1998). Dexter (2004) related their SPQ index, $S$, to soil porosity, noting that a combination of textural and structural pores is necessary for good SPQ. However, the observed soil density and porosity values may not limit water transmission and uptake, or hinder root penetration since the loamy sand-textured soils are permeable and uniformly deep (Babalola and Obi, 1981).

Saturated hydraulic conductivity, $K_{s}$

Saturated hydraulic conductivity, $K_{s}$, the index of soil resistance to flow, averaged 3.10 and $10.6 \mathrm{~cm} \mathrm{~h}^{-1}$ on NA and SA, respectively (Table 1), representing $70.75 \%$ significantly $(p<0.05)$ lower on the former than the latter. It appeared to reflect the trend in particle-size fractions and soil bulk density. In 2000, $K_{s}$ was $49.85 \%$ higher on NA than SA (Table 2). During the 20 -year period, $K_{s}$ declined by $93.03 \%$ on NA and $52.47 \%$ on SA (Tables 1 and 2), indicating severe reductions in water transmission rate in the soils, which might be due to the marginal increases in total pores since small changes in soil porosity/pore-size distribution result in orders of magnitude of change in hydraulic conductivity. Compared to $<1.8 \mathrm{~cm} \mathrm{~h}^{-1}$ critical value for very low water movement and $1.8-18.0 \mathrm{~cm} \mathrm{~h}^{-1}$ optimal range for water movement (Pulido Moncada et al., 2015), the ranges of values in Tables 1 and 2 show that the soils were disposed to water entry and movement.

The $K_{S}$ is an important soil hydrological property influencing water movement/retention in saturated and unsaturated soils. It integrates the effects of soil texture and structure and management on soil water (Anderson and Bouma, 1973; Bouma, 1981). It exerts a dominating influence on the partitioning of rainfall into vertical and lateral flow paths (Zimmermann et al., 2013), and influences the flow regime of water in the soil profile.
An important soil function and an index of good SPQ is that the soil accepts, stores and transfers the water for crop uptake. The results of this study showed that the soils may be inhibited in this function, requiring soil management practices that would improve infiltration and plant available water capacity (PAWC) on NA and SA.

Table 1: Effect of slope aspect on soil properties averaged over slope position

\begin{tabular}{|c|c|c|c|}
\hline \multirow{2}{*}{ Soil property } & \multicolumn{2}{|c|}{ Aspect } & \multirow{2}{*}{$\mathrm{LSD}_{5 \%}$} \\
\hline & North & South & \\
\hline Coarse sand $\left(\mathrm{g} \mathrm{kg}^{-1}\right)$ & 663.00 & 677.00 & 43.40 \\
\hline Fine sand $\left(\mathrm{g} \mathrm{kg}^{-1}\right)$ & 198.00 & 198.00 & 24.00 \\
\hline Total sand $\left(\mathrm{g} \mathrm{kg}^{-1}\right)$ & 862.00 & 884.00 & 25.10 \\
\hline Total silt $\left(\mathrm{g} \mathrm{kg}^{-1}\right)$ & 46.00 & 39.00 & 8.40 \\
\hline Total clay $\left(\mathrm{g} \mathrm{kg}^{-1}\right)$ & 92.00 & 77.00 & 16.70 \\
\hline Bulk density $\left(\mathrm{Mg} \mathrm{m}^{-3}\right)$ & 1.56 & 1.53 & 0.08 \\
\hline Total porosity $\left(\mathrm{m}^{3} \mathrm{~m}^{-3}\right)$ & 0.425 & 0.429 & 0.03 \\
\hline$K s\left(\mathrm{~cm} \mathrm{~h}^{-1}\right)$ & 3.10 & 10.60 & $5.05^{*}$ \\
\hline Soil organic carbon $\left(\mathrm{g} \mathrm{kg}^{-1}\right)$ & 13.80 & 14.00 & 3.20 \\
\hline WSA $(\%)$ & 66.20 & 61.30 & 6.70 \\
\hline MWD (mm) & 8.38 & 7.37 & 3.09 \\
\hline Structural index $(\%)$ & 17.20 & 20.80 & \\
\hline $\mathrm{Fe}_{\mathrm{ox}}\left(\mathrm{mg} \mathrm{g}^{-1}\right)$ & 1245.00 & 1235.00 & 181.00 \\
\hline $\mathrm{Al}_{\mathrm{ox}}\left(\mathrm{mg} \mathrm{g}^{-1}\right)$ & 341.20 & 335.90 & 30.90 \\
\hline $\mathrm{Fe}_{\mathrm{di}}\left(\mathrm{mg} \mathrm{g}^{-1}\right)$ & 1409.00 & 1340.00 & 183.30 \\
\hline $\mathrm{Al}_{\mathrm{di}}\left(\mathrm{mg} \mathrm{g}^{-1}\right)$ & 192.60 & 201.10 & 16.70 \\
\hline $\operatorname{IR}-\mathrm{i}\left(\mathrm{cm} \mathrm{h}^{-1}\right)$ & 0.51 & 0.57 & 0.12 \\
\hline IR-f $\left(\mathrm{cm} \mathrm{h}^{-1}\right)$ & 0.19 & 0.12 & $0.06^{* *}$ \\
\hline Cum-I (cm) & 34.00 & 21.0 & $9.95 *$ \\
\hline Sorptivity $\left(\mathrm{cm} \mathrm{h}^{-1 / 2}\right)$ & 0.51 & 0.69 & $0.18^{*}$ \\
\hline Transmissivity $\left(\mathrm{cm} \mathrm{h}^{-1}\right)$ & 0.23 & 0.14 & $0.05 * *$ \\
\hline $\begin{array}{l}\text { *significant at } p<5 \% ; * * \text { sig } \\
K s \text { - saturated hydraulic cond } \\
\text { IR-i initial infiltration rate; IR } \\
\text { Cum-I - cumulative infiltratic } \\
\text { WSA - water stable aggregat } \\
\mathrm{Fe}_{\mathrm{ox}} \text { - oxalate } \mathrm{Fe} ; \mathrm{Al}_{\mathrm{ox}}-\text { oxala }\end{array}$ & $\begin{array}{l}\text { ficant at } p \\
\text { tivity; } \\
\text { - final inf }\end{array}$ & $\begin{array}{l}1 \% ; \\
\text { ation rate; }\end{array}$ & $\begin{array}{l}\text { neter; } \\
\text { CB Al }\end{array}$ \\
\hline
\end{tabular}

Table 2: Effect of slope aspect on soil physical properties averaged over slope position*

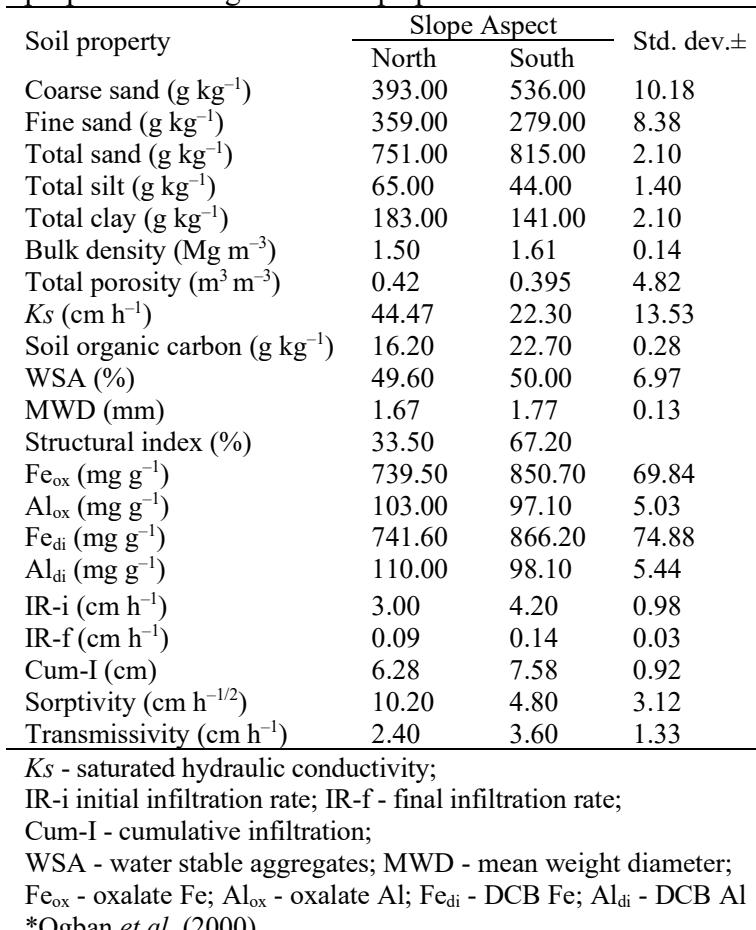

*Ogban et al. (2000). 


\section{Soil organic carbon, SOC}

The SOC content was similar on NA and SA, averaging 13.8 and $14.0 \mathrm{~g} \mathrm{~kg}^{-1}$, respectively in 2020 (Table 1), and 16.2 and $22.7 \mathrm{~g} \mathrm{~kg}^{-1}$ in 2000 (Table 2). It was $1.45 \%$ and $40.12 \%$ lower in NA than SA in 2020 than 2000, respectively. Similarly, the decline in SOC over the 20-year period was lower (14.81\%) in NA than SA (38.33\%). These losses represent an average of $26.57 \%$ carbon flight from the slopes, a significant degradation of the soil. Compared to the rating by Enwezor et al. (1990); < $11.6 \mathrm{~g} \mathrm{~kg}^{-1}$ as low, 11.6-17.4 $\mathrm{g} \mathrm{kg}^{-1}$ as medium, and $>17.4 \mathrm{~g} \mathrm{~kg}^{-1}$ as high for southeastern Nigeria soils, SOC content was in the medium range in 2020, and high in 2000, further indicating the sustained loss over the period. Also, compared to Pulido Moncada et al.'s (2015) rating; < $11.6 \mathrm{~g} \mathrm{~kg}^{-1}$ as low, 11.6-23.2 $\mathrm{g} \mathrm{kg}^{-1}$ as medium, and $>23.2 \mathrm{~g} \mathrm{~kg}^{-1}$ as high; the soils were medium in SOC concentration in Tables 1 and 2.

Generally, SOC plays vital roles in the maintenance and improvement of soil properties and functions, e.g., soil water retention and transmission, aggregate formation and stabilization against erosion and other degradative processes (Agbim and Adeoye, 1991; Lal and Shukla, 2005). Enwezor et al. (1990) described the soils in the area as low in SOC content. Enwezor et al. (1981) attributed the low content of SOC to favourable high moisture and temperature conditions that favour soil organic matter decomposition in south-eastern Nigeria. Jenkins and Ayanaba (1977) noted that decline in SOC content of cultivated soils is a direct effect of high temperatures throughout the year that enhance the mineralization of organic matter, and preferential removal of soil colloids, including the humified organic matter fraction by water erosion down slope (Lal, 1976), adversely affecting soil structural stability, infiltrability, and plant-available water reserves. It was probable that years of exposure to degradative cultivation practices (plough-bare soil surface management) had favoured SOC sequestration in the atmosphere, contributing to atmospheric radiative gases. The SOC is dynamic and sensitive to management practices and therefore can be used as an indicator of degradation of SPQ and diminishing agronomic function (Larson and Pierce, 1994; Doran and Parkin, 1996; Karlen et al., 1997; 1998; Obalum et al., 2017), requiring the use of plant residues, manures and rotational fallow to improve SOC storage.

Effect of Slope Aspect on Aggregate Stability Water-stable aggregates $\&$ mean-weight diameter The indices of soil structural stability, \%WSA and MWD averaged respectively $66.2 \%$ and $61.3 \%$ and $8.38 \mathrm{~mm}$ and $7.37 \mathrm{~mm}$, and were not significantly different in NA and SA (Table 1). The respective average values in Table 2 are $49.6 \%$ and $50.0 \%$, and $1.67 \mathrm{~mm}$ and $1.77 \mathrm{~mm}$. The results showed that WSA was $4.90 \%$ higher in NA than SA (Table 1).
Over the evaluation period, WSA in the respective aspects was significantly higher in 2020 (60.53\%) than 2000 (55.53\%). Compared with Mukherjee and Lal (2014) and Pulido Moncada et al. (2015); $<50.0 \%$ as low, $50-70 \%$ as medium, and $>70.0 \%$ as high aggregate stability, the soils on NA and SA were categorized as very low in macrostructural stability (Table 1) and medium aggregate stability (Table 2). Similarly, MWD was not significantly different between NA and SA at each sampling period, but increased remarkably by $31.26 \%$ in NA and $21.71 \%$ in SA (Table 2 to Table 1 ).

The increases in WSA and MWD were against the trend in SOC and its depletion in the soils. The percentage WSA $(>60.0 \%)$ on the slopes indicated that macro aggregates dominated the aggregate hierarchy. And since the formation and stabilization of macrostructure is in the domain of organic matter, the residual organic matter, despite being depleted, may have caused the increases in macrostructural stability in the soils. The results of WSA and MWD were corroborated by the soil structural index, SI, whose values were on NA and SA, respectively $17.2 \%$ and $20.8 \%$ in 2020 and $33.5 \%$ and $67.2 \%$ in 2000 (Tables $1 \& 2$ ). The results also indicated that SI declined by $48.6 \%$ on NA and $69.0 \%$ on SA; the decreases in SI following the pattern of SOC depletion. However, compared to Mukherjee and Lal (2014) and Pulido Moncad et al. (2015) or Pieri (1992); < 5\% as structurally degraded soil, 5-7\% as soil with high risk of degradation, and $>9 \%$ as soil with sufficient $C$; the soils whose data are in Tables 1 and 2 would be highly structurally stable against disruption due to tillage and raindrop impact.

With the observed values of WSA and MWD, cultivation that fragments soil structure through degradation of soil organic matter (Six et al., 1998) may not have adversely affected the soils. Indeed, the results indicated a high degree of structural stability on NA and SA, irrespective of the contrary trend in SOC content which was higher on SA where WSA and MWD were lower. The higher WSA and MWD on NA may also be attributed to less disruption of soil aggregates by raindrops (Webster and Wilson, 1980). Soil aggregate stability relates to soil resistance to raindrop impact, erosion and runoff, as well as its ability to accept, store and transmit water for crop growth. The results obtained indicated that the soil physical conditions in terms of structural porosity and stability were optimum for soil-water relations function but that quality soil management methods must be adopted to sustain the amount of SOC and stability of the soils.

\section{Fe and Al oxides}

The Ox and DCB extractable Fe and Al showed similar values but generally tended to be higher on NA than SA in 2020; Fe was higher than Al on NA and vice versa on SA in 2000 (Tables 1 and 2). Both forms of oxides were significantly higher in 2020 
than 2000. For instance, Ox extractable $\mathrm{Fe}$ and $\mathrm{Al}$ increased by $40.6 \%$ and $69.8 \%$ on NA, and by $31.0 \%$ and $71.1 \%$ on SA. Also, the more reactive $\mathrm{Fe}$ and $\mathrm{Al}$ (amorphous) oxides were less abundant than the crystalline oxides in the soils. However, $\mathrm{Fe}$ and $\mathrm{Al}$ oxides are part of the organo-mineral complexes that contribute to good soil structure by cementation of clay and stability of micro aggregates against colloidal dispersion and soil erodibility. Since the oxides are micro aggregants, it appeared that they were active in the about $40 \%$ micro structural stability in the soils. Igwe and Obalum (2013) indicated that $\mathrm{Fe}$ and $\mathrm{Al}$ oxyhydroxides play an important role in the colloidal stability of tropical soils though these oxidic substances are not easily manipulated in regular soil management practices. As indices of macroaggregate stability of soils, WSA and MWD depend not only on total amount of organic matter but more importantly on its chemical composition (Barthes et al., 2008). Hence, soil management must emphasize organic matter and its composition as a means of protecting macro aggregates against breakdown to micro aggregates, erosion and deterioration of SPQ on the Farm.

\section{Effect of Slope Aspect on Water Infiltration Water intake}

Initial infiltration rate (IR-i) being water intake in the first $1 \mathrm{~min}$. averaged 0.51 and $0.57 \mathrm{~cm} \mathrm{~h}^{-1}$ in 2020 (Table 1) and 3.0 and $4.2 \mathrm{~cm} \mathrm{~h}^{-1}$ in 2000 (Table 2) on NA and SA, respectively. The effect of aspect on IR-i was similar. Notably, its pattern of differences resembled that of particle-size fractions, indicating that textural pores may have controlled the simulated acceptance of rainwater. However, final infiltration rate (IR-f) and cumulative infiltration (Cum-I) were significantly higher on NA than SA in 2020 and vice versa in 2000 (Tables 1 and 2). Over the 20 -year period, IR-i declined by $83.0 \%$ on NA and $86.43 \%$ on SA; IR-f increased by $52.63 \%$ on NA and decreased by $14.29 \%$ on SA; and Cum-I increased by $81.53 \%$ on NA and $63.9 \%$ on SA.

Infiltration is one of the rapidly changing, highly dynamic characteristics of the soil (Sparling, 2008). Thus, since IR-i decreased by $>80 \%$ over the period, soil texture did not influence it in the $30-\mathrm{cm}$ depth. This was probably because the rains occurred in storms and ponded rapidly to the detriment of infiltration. It was also probable that the soil pores below the $30-\mathrm{cm}$ depth had been clogged by the finer particle-size fractions depleted from the topsoil layers affecting $K_{s}$ and downward flow. Consequently, the low infiltration rate generally and the decreases within 20 years were attributed largely to rainfall characteristics. However, it also appeared that Cum-I increased as reflected in the > $80 \%$ on NA compared to $>60 \%$ on SA, which would be good for the water economy of the rooting zone especially in NA, provided that it would not be lost to deep percolation.
Compared to the average monthly rainfall depth of about $200 \mathrm{~cm}$ in the area (Udosen, 2017), the Cum-I indicated that much of rainwater was lost in runoff, but more on SA than NA. Also, the IR-f, an index of the maximum flux of water into the soil, was low on NA and SA. Since IR-f varies with soil texture and structure, and indirectly with $K s$, IR-1 and Cum-I would increase with suitable tillage and residue management on the Farm, as surface residue helps to conserve soil moisture (Ogban, 2017).

\section{Sorptivity and transmissivity}

Soil water sorptivity, $S$, was significantly $(p<0.05)$ higher on SA than NA in 2020 but on NA than SA in 2000; the reverse was the situation for soil water transmissivity, $A$ (Tables 1 and 2). Over the 20 years, $S$ decreased by $95.0 \%$ in NA and $85.63 \%$ in SA, while $A$ decreased by $90.42 \%$ in NA and $96.11 \%$ in SA. These results imply serious deterioration of SPQ and the soils' ability to perform soil-water relations function, and explain the low values of Cum-I recorded on both aspects of the Farm.

Soil sorptivity, $S$, reflects the cumulative amount of water infiltrated into the soil at the early stages of infiltration. It depends on initial moisture content, time and the absorptive forces that usually govern the early stages of infiltration. These forces being functions of pore-size distribution in the soils are more effective in fine-textured soils with dominance of capillary pores than in coarse-textured soils dominated by drainage pores. Results have shown that the 30-cm soil depth was coarse-textured and characterised by drainage pores with low capillarity, and this could explain the values observed of $S$ and $A$. However, to regenerate the soils and improve their water retention capacity, suitable soil management practices such as rotational fallows and the use of manures and crop residues are needed so that the organic matter will bond the primary particles, form and stabilize soil aggregates, maintain infiltration at high rates and increase the magnitude of $S$ and $A$ and soil moisture storage in the root zone depth.

\section{Effect of Slope Position on Basic Soil Properties}

The effect of slope position on soil properties showed that the particle-size fractions, bulk density and total pore space were not significantly different among the three slope positions (Table 3). However, there was a general trend of decreases in the values of the mechanical separates from US to MS, followed by an increase in the LS. For instance, while total sand was lowest at US and highest at MS, clay fraction and soil bulk density were highest at US and lowest at MS on both aspects. Similarly, there were no differences in $K_{s}$ among the slope positions, but $K_{s}$ increased from US $\left(4.7 \mathrm{~cm} \mathrm{~h}^{-1}\right)$ to MS $\left(9.1 \mathrm{~cm} \mathrm{~h}^{-1}\right)$ and decreased down the slope $\left(6.8 \mathrm{~cm} \mathrm{~h}^{-1}\right)$. With Table 2 as baseline, the results (Table 3) indicated the effect of erosion on the mechanical properties in the $30-\mathrm{cm}$ soil depth. 
Table 3: Effect of slope position on soil properties averaged over slope aspect

\begin{tabular}{|c|c|c|c|c|}
\hline \multicolumn{5}{|c|}{ Slope position } \\
\hline Soil property & Upper & Middle & Lower & $\mathrm{LSD}_{5 \%}$ \\
\hline Coarse sand $\left(\mathrm{g} \mathrm{kg}^{-1}\right)$ & 659.00 & 690.00 & 661.00 & 53.20 \\
\hline Fine sand $\left(\mathrm{g} \mathrm{kg}^{-1}\right)$ & 205.00 & 280.00 & 210.00 & 29.60 \\
\hline Total sand $\left(\mathrm{g} \mathrm{kg}^{-1}\right)$ & 864.00 & 883.00 & 871.00 & 30.70 \\
\hline Total silt $\left(\mathrm{g} \mathrm{kg}^{-1}\right)$ & 45.00 & 39.00 & 43.00 & 10.20 \\
\hline Total clay $\left(\mathrm{g} \mathrm{kg}^{-1}\right)$ & 91.00 & 78.00 & 86.00 & 20.50 \\
\hline Bulk density $\left(\mathrm{Mg} \mathrm{m}^{-3}\right)$ & 1.58 & 1.51 & 1.54 & 0.098 \\
\hline Total porosity $\left(\mathrm{m}^{3} \mathrm{~m}^{-3}\right)$ & 0.407 & 0.447 & 0.427 & 0.042 \\
\hline$K s\left(\mathrm{~cm} \mathrm{~h}^{-1}\right)$ & 4.70 & 9.10 & 6.80 & 6.18 \\
\hline Soil organic carbon $\left(\mathrm{g} \mathrm{kg}^{-1}\right)$ & 13.80 & 15.10 & 12.80 & 3.97 \\
\hline WSA $(\%)$ & 62.50 & 67.70 & 61.00 & 8.30 \\
\hline MWD (mm) & 6.71 & 5.88 & 11.04 & $3.78^{*}$ \\
\hline $\mathrm{Fe}_{\mathrm{ox}}\left(\mathrm{mg} \mathrm{g}^{-1}\right)$ & 1141.00 & 1261.00 & 1317.00 & 221.70 \\
\hline $\mathrm{Al}_{\mathrm{ox}}\left(\mathrm{mg} \mathrm{g}^{-1}\right)$ & 327.10 & 330.50 & 358.10 & 37.80 \\
\hline $\mathrm{Fe}_{\mathrm{di}}\left(\mathrm{mg} \mathrm{g}^{-1}\right)$ & 1487.00 & 1362.00 & 1275.00 & 224.50 \\
\hline $\mathrm{Al}_{\mathrm{di}}\left(\mathrm{mg} \mathrm{g}^{-1}\right)$ & 193.10 & 201.50 & 195.90 & 20.50 \\
\hline IR-i $\left(\mathrm{cm} \mathrm{h}^{-1}\right)$ & 0.63 & 0.54 & 0.46 & 0.15 \\
\hline $\operatorname{IR}-\mathrm{f}\left(\mathrm{cm} \mathrm{h}^{-1}\right)$ & 0.22 & 0.13 & 0.11 & $0.07 * *$ \\
\hline Cum-I (cm) & 39.7 & 23.3 & 19.50 & $12.20 *$ \\
\hline Sorptivity $\left(\mathrm{cm} \mathrm{h}^{-1 / 2}\right)$ & 0.67 & 0.62 & 0.51 & 0.22 \\
\hline Transmissivity $\left(\mathrm{cm} \mathrm{h}^{-1}\right)$ & 0.27 & 0.14 & 0.15 & $0.06 * *$ \\
\hline
\end{tabular}

The SOC concentration was similar among the slope positions (Table 3), and the pattern of variation was similar to the mechanical properties; results supporting Lal (1976) on the preferential removal of soil colloids (including humified organic matter) by water erosion down sloping lands. It could be inferred from the data that since SOC content was medium (Enwezor et al., 1990; Pulido Moncada et al., 2015), the many years of cultivation sustained low levels of SOC in the soil, contrary to Enwezor et al. (1981) that intensive cultivation depletes SOC. However, there was a decline in SOC here, and viable soil management practices, e.g., rotational fallowing, are needed to store SOC in the soils.

\section{Effect of Slope Position on Aggregate Stability and Infiltration Characteristics}

The data in Table 3 show that over $60.0 \%$ of the sand-free aggregates estimated by WSA were stable and similar on US, MS and LS of NA and SA. It appeared that the decreases in SOC did not affect the status of WSA in the soils over the 20-year period. This was corroborated by the increases in MWD at all slope positions over their average values in Table 2. Since SOC enhances macro-structural stability (Tisdall and Oades, 1982), it is probable that the available organic matter was effective in the aggregation process. Consequently, the use of crop residues and manures would improve SOC content and sustain aggregate stability in the soils.

The IR-i and $S$ were not significantly different, while IR-f, Cum-I and $A$ differed $(p<0.05)$ among the slope positions (Table 3 ). The IR-i decreased down the slope, while IR-f was significantly higher at US than MS and LS. Compared to the average values in Table 2, the infiltration characteristics decreased significantly at the slope positions during the 20 -year period, indicating loss in the fitness of the soil to accept water, i.e., that a great proportion of rainwater was lost as runoff on the farm. With the observed degradation in mechanical, aggregate and hydrological properties, portray by the data in Tables 1-3, there is the need for quality soil surface management techniques on the slopes for erosion control and moisture conservation. Soil management practices as incorporation of residues and manures and ploughing across the slopes would form the basis for enhancing structural stability, cumulative depth of infiltrated water, and soil moisture storage.

\section{Identification of Management Factors for the Teaching and Research Farm}

Pearson's correlation coefficients among the soil properties showed significant $(p<0.05)$ correlations in 28 out of 190 soil property pairs (Table 4). Although the frequency of correlation was low, it still indicated that the soil attributes could be grouped into factors based on their correlation patterns. Positive significant correlations existed between IR-f and Cum-I and $A$, total silt and total clay, Cum-I and $A, \mathrm{Fe}_{\mathrm{ox}}$ and $\mathrm{Fe}_{\mathrm{di}}$, IR-i and $S$, and coarse sand and total sand. The strongest negative correlations were between total sand and total silt and total clay, coarse sand and total silt, coarse sand and total clay, coarse sand and fine sand, and soil bulk density and total porosity. The significant correlations mostly involved particle-size fractions, bulk density, total porosity and water intake rate. The positive significant correlations between total porosity and $K_{s}$ and between $K_{s}$ and IR-I min and $S$ indicated the influence of pore space on water intake rate and post-intake soil water distribution.

The PCA was used to group the soil attributes into seven soil management factors (Table 5), and each of the selected factors had eigen values $>1$ (Table 6). The essence of these factors was to identify 
Table 4: Correlations matrix of soil properties on the University of Uyo Teaching and Research Farm

\begin{tabular}{|c|c|c|c|c|c|c|c|c|c|c|c|c|c|c|c|c|c|c|c|}
\hline Soil prop. & . CS & FS & TS & TSilt & TClay & $\mathrm{BD}$ & $\mathrm{TP}$ & $K_{s}$ & IR-i & IR-f & Cum-I & $S$ & $A$ & WSA & MWD & SOC & $\mathrm{Fe}_{\mathrm{ox}}$ & $\mathrm{Al}_{\mathrm{ox}}$ & $\mathrm{Fe}_{\mathrm{di}}$ \\
\hline$\overline{\text { FSand }}$ & $-.733^{* *}$ & 1 & & & & & & & & & & & & & & & & & \\
\hline TSand & $.755^{* *}$ & -.286 & 1 & & & & & & & & & & & & & & & & \\
\hline TSilt & $-.755^{* *}$ & .286 & $-1.0^{* *}$ & 1 & & & & & & & & & & & & & & & \\
\hline TClay & $-.755^{* *}$ & .286 & $-1.0^{* *}$ & $1.0^{* *}$ & 1 & & & & & & & & & & & & & & \\
\hline $\mathrm{BD}$ & -.123 & .224 & -.133 & .133 & .133 & 1 & & & & & & & & & & & & & \\
\hline $\mathrm{TP}$ & .313 & $-.425^{*}$ & .230 & -.230 & -.230 & $-.739^{* *}$ & 1 & & & & & & & & & & & & \\
\hline$K_{s}$ & .287 & -.244 & .349 & -.349 & -.349 & $-.586^{* *}$ & $.637^{* *}$ & 1 & & & & & & & & & & & \\
\hline IR-i & .113 & -.182 & .113 & -.113 & -.113 & -.276 & .313 & $.442^{*}$ & 1 & & & & & & & & & & \\
\hline IR-f & .001 & -.164 & -.197 & .197 & .197 & -.105 & .080 & .071 & $.600^{* *}$ & 1 & & & & & & & & & \\
\hline Cum-I & -.001 & -.162 & -.196 & .196 & .196 & -.102 & .080 & .073 & $.605^{* *}$ & $1.0^{* *}$ & 1 & & & & & & & & \\
\hline . & .050 & -.080 & .169 & -.169 & -.169 & -.301 & .259 & $.494^{*}$ & $.777^{* *}$ & .179 & .185 & 1 & & & & & & & \\
\hline 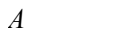 & -.046 & -.096 & -.229 & .229 & .229 & -.113 & .000 & .027 & $.614^{* *}$ & $.981^{* *}$ & ${ }^{*} .981^{* *}$ & .222 & 1 & & & & & & \\
\hline WSA & .137 & $-.519^{* *}$ & -.184 & .184 & .184 & .087 & .108 & -.193 & .001 & .377 & .375 & -.338 & .282 & 1 & & & & & \\
\hline MWD & -.090 & .057 & -.208 & .208 & .208 & .016 & -.080 & -.218 & -.152 & .029 & .021 & -.234 & .073 & -.036 & 1 & & & & \\
\hline SOC & .239 & -.292 & -.138 & .138 & .138 & -.090 & .212 & .051 & -.077 & .014 & .008 & -.176 & -.054 & .151 & .166 & 1 & & & \\
\hline $\mathrm{Fe}_{\text {ox }}$ & .154 & $-.443^{*}$ & -.141 & .141 & .141 & .171 & .051 & -.103 & .234 & .306 & .303 & .070 & .259 & $.531^{* *}$ & .117 & .231 & 1 & & \\
\hline $\mathrm{Al}_{\mathrm{ox}}$ & .251 & -.132 & .080 & -.080 & -.080 & .262 & .154 & .052 & -.074 & -.296 & -.296 & -.052 & -.286 & -.012 & .062 & .248 & .125 & 1 & \\
\hline $\mathrm{Fe}_{\mathrm{di}}$ & .119 & -.279 & -.191 & .191 & .191 & .294 & -.026 & -.072 & .140 & $.440^{*}$ & .434 & -.025 & .382 & .322 & .157 & .247 & $.805^{* *}$ & .058 & 1 \\
\hline $\mathrm{Al}_{\mathrm{di}}$ & -.009 & -.004 & .003 & -.003 & -.003 & .175 & .041 & .061 & -.368 & -.369 & -.371 & $-.412^{*}$ & $-.441^{*}$ & .035 & .109 & .147 & .258 & .035 & .322 \\
\hline
\end{tabular}

some viable soil and water management techniques for improving and sustaining the soil functions for crop production on the Farm. The seven factors explained $87.7 \%$ of the variability in soil properties. The first factor was termed water intake factor because it had high positive loadings ( $>0.90)$ on $A$, IR-f and Cum-I, moderate positive loading $(>0.70)$ on IR-i and moderate negative loading $(>0.60)$ on $\mathrm{Al}_{\mathrm{di}}$, and explained $23.5 \%$ of the total variance. The ability of a soil to accept and store water is a key soil function for agricultural productivity. This first factor thus demonstrated the need water conservation in the root zone for sustainable crop production in the coarse-textured soil on NA and SA.

The second factor was termed soil texture factor because it had high positive loadings $(>0.90)$ for total silt and total clay and high negative loadings $(>0.80)$ for total sand and coarse sand and (Table 4), and explained $22.4 \%$ of the total variance (Table 5). Soil texture affects the physical and chemical fertility of the soil. It is a static soil property that could be managed through the application of organic inputs that would improve soil aggregation. The $1.1 \%$ difference in percentage variance between the intake factor and soil texture factor indicated that the proper management of the latter, being critical limiting factor for water intake and retention, is important in the water economy of the root zone.

The third factor was termed the pore space factor because it had high positive loadings $(>0.80)$ on total porosity and moderate positive loading $(>0.70)$ on $K_{s}$ and high negative loading $(>0.80)$ on soil bulk density (Table 4 ), and explained $14.5 \%$ of the total variance (Table 5). Pore space geometry is an important hydraulic property. The texture of the soil indicated that its porosity was dominated by macro or drainage pores and that the soil was susceptible to moisture stress even in the rainy season. Pore space-induced moisture stress could be managed by the application of organic residues that could improve the moisture retention capacity of the soil.

Oxides characterised factors 4 and 6 and both were termed $\mathrm{Fe}$-Al oxide factor. Factor 4 had positive loadings $(>0.80)$ on $\mathrm{Fe}_{\mathrm{ox}}$ and $\mathrm{Fe}_{\mathrm{di}}$, and moderate positive loading $(>0.60)$ on $\mathrm{Al}_{\mathrm{di}}$ and explained $9.6 \%$ of the total variance; factor 6 had high positive loading ( $>0.80$ ) on $\mathrm{Al}_{\mathrm{ox}}$ and explained $5.7 \%$ of the total variance (Tables 4 and 5). Both crystalline $\left(\mathrm{Fe}_{\mathrm{di}}\right.$ and $\left.\mathrm{Al}_{\mathrm{di}}\right)$ and poorly crystalline $\left(\mathrm{Fe}_{\mathrm{ox}}\right.$ and $\left.\mathrm{Al}_{\mathrm{ox}}\right)$ oxyhydroxides are responsible for microaggregation in deeply weathered tropical soils, compensating for the low contents of organic matter in them (Igwe et al., 1995; Igwe and Obalum, 2013). Again, the addition of organic residues would enhance the formation of stable macroaggregates and reduce the removal of finer particles and microaggregates.

Factors 5 and 7 were termed WSA and $M W D$ factor or soil structural stability factor because of high positive loadings ( $>0.80$ ) on WSA and MWD (Table 4), and explained $6.7 \%$ and $5.3 \%$ of the total variance, respectively (Table 5). The WSA and MWD are indices of macroaggregate stability. Although the rankings showed that WSA was relatively more important than MWD, both are needed for enhanced moisture and nutrient conservation, carbon sequestration and checking of soil erosion to improve and sustain the productive capacity of the soils for increases in crop production on the Farm. Although the principal component factors are statistical constructs, they combine the inherent soil properties for focusing of quality soil management.

Table 5: Rotated component matrix

\begin{tabular}{lccccccc}
\hline \multicolumn{7}{c}{ Rotated Component Matrix } \\
\hline CSand & 1 & 2 & 3 & 4 & 5 & 6 & 7 \\
FSand & .059 & -.843 & .170 & .111 & .295 & .289 & .055 \\
TSand & -.099 & .392 & -.344 & -.277 & -.576 & -.302 & .078 \\
TSilt & .099 & .972 & -.101 & -.071 & -.086 & -.032 & -.087 \\
TClay & .099 & .972 & -.101 & .071 & .086 & .032 & .087 \\
Bd & -.114 & .038 & -.878 & .276 & -.086 & .032 & .087 \\
Tp & .022 & -.146 & .882 & .034 & .136 & .175 & -.079 \\
Ksat & .050 & -.260 & .785 & .077 & -.264 & .012 & -.013 \\
IR-1 & .716 & -.106 & .348 & .142 & -.344 & .133 & -.282 \\
IR-f & .934 & .094 & .051 & .166 & .149 & -.152 & .050 \\
Cum-I & .935 & .094 & .050 & .164 & .145 & -.153 & .040 \\
S & .390 & -.103 & .369 & .023 & -.597 & .208 & -.418 \\
A & .957 & .123 & .002 & .095 & .059 & -.135 & .069 \\
WSA & .243 & .099 & -.038 & .276 & .829 & .025 & -.137 \\
MWD & .050 & .115 & -.074 & .083 & -.099 & .063 & .874 \\
SOC & -.063 & .104 & .262 & .178 & .296 & .475 & .412 \\
Fe $_{\text {ox }}$ & .231 & .048 & -.031 & .834 & .233 & .203 & -.042 \\
$\mathrm{Al}_{\text {ox }}$ & -.238 & -.084 & -.067 & .079 & -.034 & .842 & .024 \\
Fe $_{\text {di }}$ & .294 & .063 & -.115 & .871 & .098 & .073 & .138 \\
$\mathrm{Al}_{\text {di }}$ & -.614 & .008 & .069 & .636 & .044 & -.270 & .170 \\
\hline
\end{tabular}


Table 6: Total variance explained by the factors

\begin{tabular}{lccc}
\hline \multirow{2}{*}{ Components } & \multicolumn{3}{c}{ Eigen values } \\
\cline { 2 - 4 } & Total & \% of Variance & Cumulative \% \\
\hline 1 & 4.693 & 23.467 & 23.467 \\
2 & 4.481 & 22.405 & 45.871 \\
3 & 2.909 & 14.547 & 60.418 \\
4 & 1.928 & 9.639 & 70.057 \\
5 & 1.338 & 6.692 & 76.749 \\
6 & 1.134 & 5.672 & 82.421 \\
7 & 1.051 & 5.256 & 87.677 \\
\hline
\end{tabular}

\section{CONCLUSION}

The study evaluated the effect of slope aspects and positions on soil physical quality (SPQ) at the University of Uyo Teaching and Research Farm over a 20-year period and proffered management factors for sustainable crop production on the Farm. Virtually all indicators of SPQ namely particle-size fractions, bulk density and total porosity, $K_{s}$, SOC, infiltration characteristics (IR-i, IR-f, Cum-I, $S$ and $A$ ), and oxides of $\mathrm{Fe}$ and $\mathrm{Al}$ declined remarkably, while WSA, MWD and SI remained relatively unchanged on NA and SA and slope positions over the 20-year period. The decreases in the SPQ attributes indicated serious soil degradation. The PCA identified seven factors that could guide quality soil management on the Farm namely (1) water intake, (2) soil texture, (3) pore space, (4) and (6) Fe and Al oxide, and (5) and (7) structural stability. The importance of water infiltration, storage and transfer function expressed by the status of particle-size fractions and infiltration characteristics was underscored by PCA factors 1, 2 and 3; factors 2 and 3 being the determinants of factor 1 and soil moisture retention and release capacity. The PCA factors could thus aid the selection of SPQ conservation and management techniques for sustainably improving the productive capacity of the soils on the slope aspects of the Farm. The recommended quality soil management practices include adoption of rotational fallows and application of crop residues, manures and organomineral fertilizers. Ploughing across the slope to incorporate the organic materials would generate organic matter for increased aggregation of the soils, translating into improved infiltration, water retention capacity and hence erosion resistance on the Farm.

\section{REFERENCES}

Aduloju M.O. and Tetengi M. (2011). Physical and chemical properties of soils in a toposequence in Mokwa, Niger State, Nigeria. Crop Res., 42 (1-3), 144-147

Agbim N.N. and Adeoye K.B. (1991). The role of crop residues in soil fertility maintenance and conservation. In: Organic Fertilizer in the Nigerian Agriculture: Present and Future. Proc. National Organic Fertilizer Seminar, Kaduna, 26-27 Mar. 1991. Federal Ministry of Agriculture \& Natural Resources, Abuja. pp. 21-42

Akamigbo F.O.R. and Nnaji G.U. (2011). Climate change and Nigerian soils: Vulnerability, impact and adaptation. Agro-Science, 10 (1), 80-90

Anderson J.L. and Bouma J. (1973). Relationships between saturated hydraulic conductivity and morphometric data of an argillic horizon. Soil Sci. Soc. Am. Proc., 37, 408-413

Andrews S.S., Karlen D.L. and Cambardella C.A. (2002). The soil management assessment framework: A quantitative soil quality evaluation method. Soil Sci. Soc. Am. J., 68, 1945-1962
Aparicio V. and Costa J.L. (2007). Soil quality indicators under continuous cropping systems in the Argentinean pampas. Soil Tillage Res., 96, 155-165

Arshad M.A. and Coen G.M. (1992). Characterization of soil quality: Physical and chemical criteria. Am. J. Alter. Agric., 7, 25-31

Arshad M.A., Lowery B. and Grossman R.B. (1996). Physical tests for monitoring soil quality. In: Doran J.W. and Jones A.J. (eds.), Methods for Assessing Soil Quality (pp. 123-141). SSSA Spec. Publ. No. 49. SSSA, Madison, WI

Babalola O. and Obi M.E. (1981). Physical properties of the acid sands in relation to land use. In: Udo E.J. and Sobulo R.A. (eds.), Acid Sands of Southern Nigerian (pp. 27-55). Soil Science Society of Nigeria (SSSN) Spec. Publ. Monogr. No.1

Barthes B.G., Kouakoua E., Larre-Larrouy M., et al. (2008). Texture and sesquioxide effects on waterstable aggregates and organic matter in some tropical soils. Geoderma, 143, 14-25

Bouma J. (1981). Comment on micro-, meso- and macroporosity of soil. Soil Sci. Soc. Am. J. 45, 1244-1245

Brejda J.J., Moorman T.B., Karlen D.L. and Dao T.H. (2000). Identification of regional soil quality factors and indicators: I. Central and Southern High Plains. Soil Sci. Soc. Am. J., 64, 2115-2124

Cambardella C.A., Moorman T.B., Andrews S.S. and Karlen D.L. (2004). Watershed-scale assessment of soil quality in the Loess Hills of South-western Iowa. Soil Tillage Res., 78, 237-248

Carter M.R., Gregorich E.G., Anderson D.W., Doran J.W., Janzen H.H. and Pierce F.J. (1997). Concepts of soil quality and their significance. In: Gregorich E.G. and Carter M.R. (eds.), Soil Quality for Crop Production and Ecosystem Health. Elsevier Science Publishers, Amsterdam, Netherlands

Chikezie I.A., Eswaran H., Asawalam D.O. and Ano A.O. (2010). Characterization of two benchmark soils of contrasting parent materials in Abia State, southeastern Nigeria. Global J. Pure Applied Sci., 16 (1), 23-29

Churchman G.J. and Tate K.R. (1987). Stability of aggregates of different size grades in allophanic soils from volcanic ash in New Zealand. J. Soil Sci., 38, 19-27

Dexter A.R. (2004). Soil physical quality: Theory, effects of soil texture, density, and organic matter, and effects on root growth. Geoderma, 120, 201-214. DOI: 10.1016/j.geoderma.2003.09.004

Dexter A.R. and Czyz E.A. (2000). Soil physical quality and the effects of management practices. In: Wilson M.J. and Maliszewska-Kordybach B. (eds.), Soil Quality, Sustainable Agriculture and Environmental Security in Central and Eastern Europe (pp. 153-165). NATO Science Series 2, Environmental Security, 69, Kluwer Academic Publishers, Dordrecht

Dexter A.R. and Czyż E.A. (2007). Applications of $S$ theory in the study of soil physical degradation and its consequences. Land Degrad. Dev., 18, 369-381. DOI: 10.1002/ldr.779

Doran J.W. and Parkin T.B. (1996). Defining and assessing soil quality. In: Doran J.W. et al. (ed.), Defining Soil Quality for a Sustainable Environment (pp. 3-21). SSSA Spec. Publ. 35, SSSA and ASA, Madison, WI

Doran J.W. and Jones A.J. (1996). Methods for Assessing Soil Quality. Soil Sci. Soc. Am. Spec. Publ., 49. Soil Sci. Soc. Am., Madison, WI

Dumanski J. and Pieri C.J.M. (2000). Land quality indicators: Research plan. Agric. Ecosys. Environ., 81, 93-102

Dunteman G.H. (1989). Principal Components Analysis. Sage Publ. London 
Enwezor W.O., Udo E.J. and Sobulo R.A. (1981). Fertility status and productivity of the acid sands. In: Udo E.J. and Sobulo R.A. (eds.), Acid Sands of Southern Nigerian (pp. 56-73). Soil Science Society of Nigeria (SSSN) Spec. Publ. Monogr. No. 1

Enwezor W.O., Ohiri A.C., Opuwaribo E.E. and Udo E.J. (1990). A review of fertilizer use on crops in southeastern zone of Nigeria. In: Literature Review on Soil Fertility Investigations in Nigeria (pp. 49-100). Federal Ministry of Agriculture \& Natural Resources, Lagos

Evans I.S. (1972). General geomorphology, derivatives of altitude and descriptive statistics. In: Chorley R.J. (ed.), Spatial Analysis in Geomorphology (pp. 17-90). Mathuen, London

FAO (2014). World Reference Base for Soil Resources. International Soil Classification System for Naming Soils and Creating Legends for Soil Maps. World Soil Resources Reports No. 106. FAO/WRB/IUSS Working Group, Food and Agriculture Organisation, Rome

Flint L.E. and Flint A.L. (2002). Porosity. In: Methods of Soil Analysis, Physical Methods, Part 4 (pp. 241-254). Soil Sci. Soc. Am. Book Series 5. Madison, W1, USA

Franzluebbers A.J. (2002). Water infiltration and soil structure related to organic matter and its stratification with depth. Soil \& Tillage Res., 66, 197-205

Gee G.W. and Or D. (2002). Particle-size analysis. In: Methods of Soil Analysis. Physical Methods, Part 4 (pp. 255-293). Soil Sci. Soc. Am. Book Series 5. Madison, W1, USA

Geroy I.J., Gribb M.M., Marshall H.P., Chandler D.G., Benner S.G. and McNamara J.P. (2011). Aspect influence on soil water retention and storage. Hydrol. Processes, 25, 3836-3842. DOI: 10.1002/hyp.8281

Grossman R.B. and Reinsch T.G. (2002). Bulk density and Linear Extensibility. In: Methods of Soil Analysis. Physical Methods. Part 4 (pp. 201-228). Soil Sci. Soc. Am. Book Series 5. Madison, W1, USA

Herrick J.E., Brown J.R., Tugel A.J., Shave P.L. and Havstad K.M. (2002). Application of soil quality to monitoring and management: Paradigms from rangeland ecology. Agron. J., 94, 3-11

Hillel D. (1980). Fundamentals of Soil Physics. Academy Press, New York. p 481

Igwe C.A., Akamigbo F.O.R. and Mbagwu J.S.C. (1995). Physical properties of soils of south-eastern Nigeria and the roles of some aggregating agents in their stability. Soil Sci., 160, 431-441

Igwe C.A. and Obalum S.E. (2013). Microaggregate stability of tropical soils and its roles on soil erosion hazard prediction, Advances in Agrophysical Research (Chap. 8), Stanisław Grundas (Ed.), ISBN: 978-95351-1184-9, InTech, DOI: 10.5772/52473. Available from: http://www.intechopen.com/books/advances-in-agrophysical-research/microaggregate-stability-of-tropical-soilsand-its-roles-on-soil-erosion-hazard-prediction

Inyang P.E.B. (1975). Climate regions. In: Ofomata G.E.K. (ed.), Nigeria in Maps: Eastern States (pp. 27-29). Ethiope Publ. House, Midwest Mass Comm. Corp. Benin City, Nigeria

Iqbal J., Read J.J., Thomasson A.J. and Jenkins J.N. (2004). Relationships between soil-landscape and dry-land cotton lint yield. Soil Sci. Soc. Am. J., 69, 1-11

Jenkins D.S. and Ayanaba A. (1977). Decomposition of carbon $^{-14}$ labeled plant material under tropical conditions. Soil Sci. Soc. Am. J., 41, 912-916

Jenny H. (1941). Factors of Soil Formation: A System of Quantitative Pedology. McGraw-Hill, New York

Johnson R.A. and Wichern D.W. (1992). Applied Multivariate Statistical Analysis. Prentice-Hall, Englewood Cliffs, NJ
Karlen D.L. and Sttot D.E. (1994). A framework for evaluating physical and chemical indicators of soil quality. In: Doran J.W. et al. (ed.), Defining Soil Quality for a Sustainable Environment. SSSA Spec. Publ. 35. SSSA and ASA, Madison, WI

Karlen D.L., Wollenhaupt N.C., Erbach D.C., et al. (1994). Crop residue effects on soil quality following 10 years of no-till corn. Soil Tillage Res., 31, 149-167

Karlen D.L., Mausbach M.J., Doran J.W., Cline R.G., Harris R.F. and Schuman G.E. (1997). Soil quality: A concept, definition and framework for evaluation (A guest editorial). Soil Sci. Soc. Am. J., 61, 4-10

Karlen D.L., Gardner J.C. and Rosek M.J. (1998). A soil quality framework for evaluating the impact of CRP. J. Prod. Agric., 11, 56-60

Karlen D.L., Rosek M.J., Gardner J.C., et al. (1999). Conservation reserve programme effects on soil quality indicators. J. Soil Water Conserv., 54, 439-444

Karlen D.L., Andrews S.S., Doran J.W. and Wienhold B.J. (2003). Soil quality- humankind's foundation for survival. J. Soil Water Conserv., 58, 171-179

Keys to Soil Taxonomy (2020). Updated $12^{\text {th }}$ ed. (p. 371). United States Department of Agriculture (USDA)

Lal R. (1976). Soil erosion problems on an Alfisol in Western Nigeria and their control. IITA Monogr. 1. p. 208

Lal R. (1999). Soil quality and food security: The global Perspective. In: Lal R. (ed.), Soil Quality and Soil Erosion (pp. 3-16). CRC/SWCS, Boca Raton, FL

Lal R. and van Doren Jr. D.M. (1990). Influence of 25 years of continuous corn production by three tillage methods on water infiltration for two soils in Ohio. Soil Tillage Res., 16, 71-84

Lal R., Kimble J.M., Follett R.F. and Cole C.U. (1998). The potential of U.S. cropland to sequester carbon and mitigate the greenhouse effect. Sleeping Bear Press, Ann Arbor, MI

Lal R. and Shukla M.K. (2005). Principles of Soil Physics. Marcel Dekker, Inc., New York. p. 682

Larson W.E. and Pierce F.J. (1991). Conservation and enhancement of soil quality. In: Evaluation for Sustainable Land Management in the Developing World, 2: Technical Papers. Bangkok, Thailand. Int. Board Soil Res. Manage. (IBSRAM) Proc. No. 12. pp. 175-203

Larson W.E. and Pierce F.J. (1994). The dynamics of soil quality as a measure of sustainable management. In: Doran J.W. et al. (ed.), Defining Soil Quality for a Sustainable Environment (pp. 37-51). SSSA Spec. Publ. 35. SSSA and ASA, Madison, WI

Liebig M.A. and Doran J.W. (1999). Impact of organic production practices on soil quality indicators. $J$. Env. Qual., 28, 1601-1609

McKeahue J.A. and Day J.H. (1966). Dithionite and oxalate-extractable $\mathrm{Fe}$ and $\mathrm{Al}$ as aids in differentiating various classes of soils. Can. J. Soil Sci., 46, 13-22

Miller W.P. and Baharuddin M.K. (1986). Relationship of soil dispensability to infiltration and erosion of south-eastern soils. Soil Sci., 142, 235-240

Mukherjee A. and Lal R. (2014). Comparison of soil quality index using three methods. PLOS ONE 9 (8), e105981. DOI: 10.1371/journal.pone.0105981

Nelson D.W. and Sommers L.E. (1996). Total carbon, organic carbon, and organic matter. In: Sparks D.L. (ed.), Methods of Soil Analysis. Part 3. Chemical Methods. Soil Sci. Soc. Am. Book Series No. 5. Madison, Wisconson, USA

Nimmo J.R. and Perkins K.S. (2002). Aggregate stability and size distribution. In: Dane J.H. and Topp G.C. (eds.), Methods of Soil Analysis. Part 4: Physical Methods (pp. 317-328). Soil Sci. Soc. Am. Book Series 5. Madison, W1, USA 
Obalum S.E. and Obi M.E. (2013). Moisture characteristics and their point pedotransfer functions for coarsetextured tropical soils differing in structural degradation status. Hydrol. Processes, 27 (19), 2731-2735

Obalum S.E. and Obi M.E. (2014). Measured versus estimated total porosity along structure-stability gradients of coarse-textured tropical soils with lowactivity clay. Environ. Earth Sci., 72 (6), 1953-1963

Obalum S.E., Chibuike G.U., Peth S. and Ouyang Y. (2017). Soil organic matter as sole indicator of soil degradation. Environ. Monitoring Assessment, 189 (4), Article 176. DOI: 10.1007/s10661-017-5881-y

Obalum S.E., Igwe C.A., Hermansah, Obi M.E. and Wakatsuki T. (2011). Using selected structural indices to pinpoint the field moisture capacity of some coarse-textured agricultural soils in southeastern Nigeria. J. Trop. Soils, 16 (2), 151-159

Obalum S.E., Oppong J., Igwe C.A., Watanabe Y. and Obi M.E. (2013). Spatial variability of uncultivated soils in derived savanna. Int. Agrophy, 27 (1), 57-67

Ofomata G.E.K. (1981). Actual and potential erosion in Nigeria and measures for control. In: Udo E.J. and Sobulo R.A. (eds.), Acid Sands of Southern Nigerian (pp. 151-165). Soil Science Society of Nigeria (SSSN) Spec. Publ., Monogr. No.1

Ogban P.I. (2017). Effect of land use on infiltration characteristics of soils in northern Akwa Ibom State, South-eastern Nigeria. Agro-Science, 16 (3), 29-36. DOI: 10.4314 /as.v16i3.5

Ogban P.I. and Ekerette I.O. (2001). Physical and chemical properties of the coastal plain sands of south-eastern Nigeria. Nig. J. Soil Res., 2, 6-14

Ogban P.I. and Okon A.X. (2020). Effect of slope aspect and position on soil infiltrability in an Ultisol in Akwa Ibom State, Southern Nigeria. Agro-Science, 19 (2), 23-30. DOI: 10.4314/as.v19i2.4

Ogban P.I. Maduakor O. and Akwue I.P. (2000). Infiltration characteristics and erosion potentials of catenary soils in Southeastern Nigeria. Proc. 26 th Annual Conf. Soil Sci. Soc. Nig. SSSN (pp. 78-84), University of Ibadan, Ibadan, $31^{\text {st }}$ Oct. to $5^{\text {th }}$ Nov.

Ojanuga A.G., Lekwa G. and Akamigbo F.O.R. (1981). Survey, classification and genesis of acid sands. In: Udo E.J. and Sobulo R.A. (ed.), Acid Sands of Southe Nigerian (pp. 1-17). Soil Science Society of Nigeria (SSSN) Spec. Publ. Monogr. No.1

Ollinger S., Smith M., Martin M., Hallett R., Goodale C. and Aber J. (2002). Regional variation in foliar chemistry and $\mathrm{N}$ cycling among forests of diverse history and composition. Ecol., 83, 339-355

Pajasok T. and Kay B.D. (1990). Assessment of a combination of wet sieving and turbimetry to characterise the structural stability of moist aggregates. Can. J. Soil Sci., 70, 33-42

Petters S.W., Adighije C.I., Essang E.B. and Ekpo I.E. (1989). A regional hydrogeological study of rural water supply options for planning and implementation of phase II: Rural water programme in Cross River State, Nigeria. Report for Director, Rural Dev. CRSG, Nigeria

Philip J.R. (1957). Theory of infiltration: The infiltration equation and its solution. Soil Sci., 83, 345-357

Pierce F.J., Larson W.E., Dowdy R.H. and Graham W.A.P. (1983). Productivity of soil: Assessing long-term changes due to erosion. J. Soil Water Cons., 38, 39-44

Pieri C.J.M. (1992). Fertility of Soils: A Future for Farming in the West African Savannah. SpringerVerlag, Berlin. p. 348

Pulido Moncada M., Ball B.C., Gabriels D., Labo D. and Cornelius W.M. (2015). Evaluation of soil physical quality index, $S$, for some tropical and temperate medium-textured soils. Soil Sci. Soc. Am. J., 79 (1), 9-20. DOI: 10.2136/sssaj2014.06.0259
Qi Y., Darilek J.L., Huang B., Zhao Y., Sun W. and Gu Z. (2009). Evaluating soil quality indices in an agricultural region of Jiangsu Province, China. Geoderma, 149, 325-334

Rawls R.J., Gimenez G.D. and Grossman R. (1998). Use of soil texture, bulk density, and slope of water retention curve to predict saturated hydraulic conductivity. Trans. Am. Soc. Agric. Eng., 41, 983-988

Reynolds W.D. and Elrick D.E. (2002). Constant head soil core (tank) method. In: Dane J.H. and Topp G.C. (eds.), Methods of Soil Analysis. Part 4: Physical Methods (pp. 804-808). Soil Sci. Soc. Am. Book Series 5. Madison, W1, USA

Reynolds W.D., Elrick D.E. and Young E.G. (2002). Ring or cylinder infiltrometer (vadose zone). In: Dane J.H. and Topp G.C. (eds.), Methods of Soil Analysis. Part 4: Physical Methods (pp. 818-843). Soil Sci. Soc. Am. Book Series 5. Madison, W1, USA

Scott H.D. (2000). Soil Physics with Agricultural and Environmental Applications. Iowa State Univ. Press, Ames, Iowa. p. 421

Seybold C.A., Mausbach M.J., Karlen D.L. and Rogers H.H. (1997). Quantification of soil quality. In: Lal R. et al. (ed.), Soil Processes and Carbon Cycle (pp. 387-404). CRC Press, Boca Raton, FL

Shukla M.K. (2014). Soil Physics: An Introduction. CRC Press. Taylor and Francis Group. Boca Raton

Six J., Elliott E.T., Paustian K. and Doran J.W. (1998). Aggregation and soil organic matter accumulation in cultivated and native grassland soils. Soil Sci. Soc. Am. J., 62, 1367-1377

Sojka R.E. and Upchurch D.R. (1999). Reservations regarding the soil quality concept. Soil Sci. Soc. Am. $J ., 63$ (5), 1039-1054

Sparling G. (2008). Quality Indicators. In: Encyclopedia of Soil Science (pp. 1408-1411)

Stern R., Eisenberg B.E. and Laker M.C. (1991). Correlation between microaggregate stability and soil surface susceptibility to runoff and erosion. South Afr. J. Plant Soil., 8, 136-140

Tisdall J.M. and Oades J.M. (1982). Organic matter and water-stable aggregates in soils. J. Soil Sci., 33, 141-163

Udosen C. (2017). Rainfall Trends in a Humid Tropical Environment. AniHap Resources, Uyo. p. 244

Warrick A.W. and Nielsen D.R. (1980). Spatial variability of soil physical properties in the field. In: D. Hillel (ed.), Applications of Soil Physics (pp. 319-344). Acad. Press, New York

Webster C.C. and Wilson P.N. (1980). Agriculture in the Tropics $\left(2^{\text {nd }}\right.$ ed.), Tropical Agriculture Series, Longmans, p. 148

Weil R.R. and Brady N.C. (2017). The Nature and Properties of Soils $\left(15^{\text {th }}\right.$ ed.), Pearson Education Limited, England. p. 1105

Wilson M.J. and Maliszewska-Kordybach B. (2000). Soil quality, sustainable agriculture and environmental security in Central and Eastern Europe. NATO Sci. Series 2, Environmental Security, 69. Kluwer Academic Publishers, Dordrecht. pp. 375

Yaalon D.H. and Arnold R.W. (2000). Attitudes toward soils and their societal relevance: Then and now. Soil Sci., 165, 5-12

Yimer F., Ledin S. and Abdelkadir A. (2006). Soil property variations in relation to topographic aspect and vegetation community in the South-eastern highlands of Ethiopia. For. Ecol. Manag., 232, 90-99

Zimmermann A., Schinn D.S., Francke T., Elsenbeer H. and Zimmermann B. (2013). Uncovering patterns of near-surface saturated hydraulic conductivity in an overland flow-controlled landscape. Geoderma, 195196, 1-11. DOI: 10.1016/j.geoderma.2012.11.002 